\title{
Reform and Innovation of Adult high education teaching mode Dong $\mathrm{Ma}^{1, \mathrm{a}}$ \\ ${ }^{1}$ Jilin Agricultural University, Changchun, Jilin Province, China \\ amadong8487@163.com
}

Keywords: Adult education, High education, Education mode, Reform and Innovation

\begin{abstract}
Adult education as an important part of our education system, to improve the overall quality, promotes economic development and social progress plays an extremely important role. The wave of reform increasingly popularity of adult education in our country, some traditional and conservative teaching methods obviously influenced the teaching effect, and caused a serious waste of education resource. For adapt to the diversified need of adult learners in network ages, the reform of adult education classroom model must be put into practice: The teacher role changes from the single teacher and governor to the direction scholar and helper; The learner role changes from the passive learner to the independence learner; The content of course develops from the still state to the innovation; The teaching means reforms from the type of dictate writing on the blackboard to the type of multi-media teaching ; The teaching organized form reforms from the instilling type of single direction to the stereoscopic type all for learner.
\end{abstract}

\section{Introduction}

In today's rapid development of science and technology and knowledge, adult education and lifelong education has become a prerequisite for improving human quality, cultivating high-tech talents. So more and more office workers choose quit his job to return to campus, improve personal quality and professional level.

\section{The problems existing in the adult education}

In recent years, our country's adult high education in the educational condition and the scale of high education has made considerable development, especially in the current economic development in China is facing a serious shortage of natural resources and human resources, education foundation is weak, education overall supply ability is not strong, the low level of education of the labor force, under the condition of adult high education play an important role [1]. But as a result of adult high education in our country is still in use 50-70 s education mode and education system, adult education income generation, management, recruitment, training, scale, quality of unhealthy practices is forming, which seriously affect the quality of the adult high education and development.At present, China's adult high education there are three main problems.

Education management system is not perfect. Including education administrative system is imperfect and unreasonable school-running system two aspects. First of all, the adult high education belongs to a single management [1]. The adult high education only belongs to administrative department of education management, management of channels. Second, the education administrative department of the weakening of adult high education management, school on the school system still needs to be further straightening out.

The old education mode. From ordinary high education a new mode of adult high education is not a fundamental change, too much emphasis on academic and systemic, neglecting the students' ability; In the curriculum, the classroom teaching, teaching content, teaching methods and teaching means, etc, most of the common methods of high education is still the lineage, heavy theory and the practice application, the heavy teaching and create light, heavy and light personality unity, from the practical needs of social development, basically keep the thinking formulary of ordinary high education and, to some extent, become "copies" of high education. 
Adult high education position is not clear. Scientific positioning of adult high education is the basic premise to improve the quality of adult education [1]. Understanding unclear positioning of adult education in China, there are the following error: first, that the adult education, especially the adult high education is education of record of formal schooling. Is not within the framework of lifelong education to realize adult education, not in the concept of lifelong learning, all the people will learn to build the new concept of adult education. Second, the understanding of classification is the adult education of fuzzy. In that adult high education belongs to the category of high education, adult high education should be vocational education is not recognized or category of high vocational education, so the training mode design, education content, teaching methods, etc according to the ordinary high education methods in the process, does not have scientific and targeted. Third, the training goal is not clear.

\section{The necessity of adult education teaching model reform and innovation}

The several opinions about speed up the development of continuing education (draft) "on the Internet to solicit the opinions of the whole society, education is a big deal.File from the national economic and social development and education development of the global strategic height, put forward the significance of the development of continuing education, guiding ideology, main task and guarantee system construction.Education after the promulgation and the implementation plan, like a spring thunder, heralding the continue education and a spring is coming to us. File, stressed that to fully understand the importance of speed up the development of continuing education, accelerate the development of continuing education is to promote national core competitiveness and the inevitable requirement of promoting the construction of an innovative country, is to promote China's transformation of economic development patterns and industrial structure adjustment of important support, is to build a lifelong education system and the urgent needs of the construction of learning society, is a continuous development of human resources and meet the demand of the social members increasingly diversified education."Inevitable", "key support", "urgent need", "important step" these four words, from the perspective of four deep comprehensively describe the development of the strategic significance of adult education.

\section{Adult education pattern reform and innovation}

Guided by the concept of modern curriculum, outstanding professional characteristics, optimize professional Settings. Type from the course reform of the traditional method of single subject courses, course construction to continuously learn new concept of modern curriculum theory [2]. Therefore, meet the requirements for network era, and the adult classroom idea and behavior, content and form of change, there is no doubt that want to implement to teachers, students, content, means and form of the adult education mode on the change of elements of the class.

From the teaching, teachers' role managers to guide academics, scholars. Network era, the teaching content information, teaching means and form diversification, students can get knowledge from the various channels of information network, can be before teachers get has not yet had time to master advanced knowledge and cutting-edge information, by all sorts of model, the influence of the public figures or events [2].Teacher's prophetic, authoritative, single model no longer exists, so teachers must be stepped down from the pulpit of commanding, change their role position, by a imparter into promoters and converted to guide by management, by discipline into mentors.

More than this, the Internet age requires teachers to their own prophetic, authority and role models, to reflect on, the more reconstruct the meets the needs of our modern adult education teachers knowledge structure, way of learning, educational policy, in a word namely reconstruct Internet age, the authority of teachers and students grow together self-development goals. Teachers can not meet to do "a glass of water infusion, the occupant of a bucket of water", needs to be a student of the "guide" an ever-flowing stream water, must offer a "source", "charging refueling" constantly, be constantly improving learners consciously.Teach since teaching, student self-service, establish his own talent, should become the adult classroom teacher's idea and behavior consciously. 
Students from passive into autonomous learners being taught. Adult students have certain knowledge, basic ability, become autonomous learners, is not a problem.Network era, all kinds of information channel unusually rich, also for adult students grow up to be autonomous learners provides a great convenience. As a result, the adult student must correct learning attitude, change the role position, find the traditional adult class has lost self - the learner's subjectivity, remove servility, blindly, autonomy, responsibility, critical, from passive into active learners, being taught not only to adult classes as smoothly pass the exam, the effective measure to achieve a level diploma, more important is its as to obtain new knowledge and practice skills, enlightenment thought important way [3]. Teachers should also try to inspire the student to do automatic learners, researchers, autonomous innovators themselves.The era of network schools must make the object of the education the main body of education itself, by the people education must be education of his own people;Other education must be the man of your own education. The United Nations educational, scientific and cultural organization of the thesis, it is very enlightening and guiding value.

Teaching contents from static, single plane sex change for the dynamic, three-dimensional multimedia. More than ten years or decades in the same material dominates the adult class, by teachers and students as the "imperial edict", this is nothing new.Long-term creation and accumulation of human knowledge essence, undoubtedly should become the main basis of teaching and learning [3]. But as a result of too much emphasis on knowledge of systematic, cohesion and the stability of the teaching material, longer, and the teaching materials "industry monopoly" and the level of the writer, some of adult classroom teaching content is "fine bad fit", antiquated, patchwork, churning out, written, Fried rice now.Adult students to participate in classroom learning, aimed at jinde length, namely on the basis of the original German, industry in order to ascend, if the object material is been studied many times what we, or does not reflect the latest trends of the economic and social development of science and technology, or improvement of little value for the individual development and work, the study is a waste of life.

Today, the adult classroom teaching and learning materials, must be from static, aging, the single plane to dynamic, relative infinitive, novelty, moderately advanced a variety of media teaching resources in time.In a certain period of time training plan, course standard is relatively stable under the premise of adult classroom teaching can be flexible, diverse, can adopt the ordinary university's high level of teaching material, also can write high quality teaching material, also can be made of a number of speaker teachers et.al [3]. Dynamic notes, in the process of teaching should also be timely added new thoughts, new theory, new technology and other study materials; These teaching materials, including text, including audio and video, electronics, and so on various aspects of online learning resources, shows the characteristics of multimedia applications. Therefore, the development and provide new and abundant learning resources, is an important teaching step of teachers and tasks.This puts forward new and high requirements for teachers, teachers should not only strengthen the consciousness of all sorts of study resource development, improve the learning resources of technology development and innovation, and to provide learning resources, delivery skills, but also guide and tutoring students to will pick from the complicated learning resources.Although Internet age students obtain knowledge more channels, but to ensure that the adult classroom teaching content of the new, fast, accurate, real, to teacher's request is not low, but the teachers' knowledge structure, teaching skills, collaboration with high capacity requirements.

Teaching means from dictation blackboard writing style changes for multimedia integrated type. Now carry and transport information of the rapid development of multimedia, written materials is more and more exquisite, audio and video, electronic equipment and books have sprung up, take the Internet as the main body of new information transmission channels, through the network is widespread.All this for adults and receiving of the course content can be combination of diversification and enrichment of teaching means [4].The adult colleges and universities especially TV university system has a bigger development modern multimedia teaching means, make full use of wireless networks, Internet, network technology, the construction of the high-grade satellite receiving system, multimedia classrooms, electronic reading room, remote network and network classroom facilities, such as "radio and television university is not electricity" phenomenon has become a 
history. The key question now is in the good hardware on the basis of how to develop high quality software, how to make full use of the means of software and hardware, and give full play to the multimedia auxiliary teaching in adult classes, information center, counseling center, learn the student center, and other functions [4].The diversification of teaching means, multimedia, modern, comprehensive, is in today's TV university adult education of the increasingly intense competition in the market circumstances can make full use of one of the advantages of.Maximize the advantages, in the adult education gradually towards the process of industrialization, in the famous break into the adult education market in common colleges and universities, the TV university to the invincible position in fierce competition, also can get the best opportunity of survival and development of innovation.

Teaching organization form, from one-way force-feeding multidimensional vertical change. Facing the network era, information society, the trend of the industrialization, marketization and the status quo of adult education, adult class of subject, object, means, revolutionary change is bound to the changes and eventually embodies in adult classroom teaching organization form of change [5]. Adult classroom teacher, student, content and means of the four elements of different combination, constitute a variety of adult classroom teaching organization form, or what kind of organization form which is more conform to the needs of the adult education network times?How to change and innovation of adult classroom teaching organizational form? We tried the following ideas and practices, may well reasonable combination of the adult class each factor.

Let the student in charge.Determine the subject status of the adult students to it as the center of the classroom, to study for this, due to the learning theory of teaching, is the reform of traditional adult class must be set up.Adult knowledge ability and the thought foundation, rich life experience and work experience, for it becomes a real learning main body is provided, teachers should never ignore the students is the fundamental starting point and the foothold the real purpose of education, can not turn a blind eye to real body of the teaching.

Three explanations.Adult in the classroom, the teacher is the inspiration of students' autonomous learning and mentors, life growth, helper and promoter, no need to undertake to the student very system to teach or to feed "after" chew, provide more abundant learning resources, guided with critical learning after absorption, want to do is tip point, analysis, solve difficult points.

Information about fast food. Introduce in a timely manner to the economic society of latest science and technology related to professional development, and new thoughts, new ideas, new theories, new technology, new achievements, adult class can organize information fast food, for all the teachers and students to share.Can be organized by teachers, can also be organized by the students in turn;Can be a press conference, can also be online transmission;Can specially arranged a class, also can cooperate with other forms.Pay attention to the information fast, new, letters, and more.

Class market.Adult classes are really have no fixed classroom, the classroom should be like free trade market, eclectic, various learning resources, students the freedom to choose, family can review head foot, can be controversial discussion, can customize, exchangeable, critical, can absorb, can choose, can digg.According to appropriate between teachers and students in this class.

Peer learning.Adult students come from all walks of life, different experiences, experience each, is in itself quite rich learning resources.To the development and utilization of the resources, an important task of teachers is an adult class.Often experience exchange meeting or seminar, experience sharing, problems in research, complement each other, help each other.

Low case analysis. Use case or organization students according to their own practical writing case, carries on the analysis discussion, design problem solving simulation program, can cultivate theory with practice, the ability to analyze and solve problems.

Low topic discussion. Determine a key theme, decorate students make full preparations before class, class organization all students to participate in the discussion, and everyone must speak, speak freely, inspire thinking and collision.

The study of the problem of low. Adults will encounter all sorts of problems in the work and study, use the focus of study opportunity, cooperate the combination of theory and practice research, is a 
good way to solve problems and improve ability.Teachers can arrange some typical strong subject, lets the student to explore, to cultivate students' ability of research and innovation.

\section{Summary}

Adult education mode no matter how to change, then pay attention to the following points: first, teachers hold money; students hold a diploma, adult class change is impossible. Second, teaching machines will never replace teachers, high requirement for teachers can only more comprehensive and more flexiblization. Third, student is the center, all for the students, in order to all students, in order to all students. Fourth, fixed teaching material is a reference book; dynamic, multimedia material is the main study contents, the notes in the update constantly. Fifth, means and form innovation is endless, without permanent adult classroom teaching mode.

\section{References}

[1] Ch.Q. Fu, The adult continuing education studies the teaching method reform, High education in vocational studies, 2012, vol.42, 56-61.

[2] M.K. Chen, The adult education training mode innovation research, China's adult education, 2010, vol.17, pp.8-11.

[3] G.H. Wei, Adult high education reform and innovation of teaching methods, Continue education research, 2011, vol.11, pp.10-13.

[4] H. Wang and Ch.D. Zhao, High vocational colleges to continue education research, Cultivating creative personnel to continue education research, 2013, vol.1, pp.45-46.

[5] G.W. Song and H.X. Miao, Transformation of the teachers' role in network era, Education and research, 2001, vol.8, pp.32-36. 